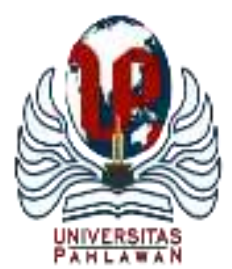

Edukatif : Jurnal Ilmu Pendidikan Volume 3 Nomor 6 Tahun 2021 Halm 5109 - 5115

EDUKATIF: JURNAL ILMU PENDIDIKAN

Research \& Learning in Education

https:/ledukatif.org/index.php/edukatif/index

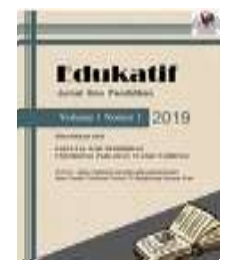

\title{
Alumni Views and the Potential of Social Impact on Career Counselling Guidance Policy at the University Level
}

\author{
Wienda Gusta ${ }^{1}$ Zakirman $^{2 凶}$, Neviyarni Suhaili ${ }^{3}$ \\ Universitas Putra Indonesia YPTK Padang, Indonesia ${ }^{1}$ \\ Universitas Terbuka, Indonesia ${ }^{2}$ \\ Universitas Negeri Padang, Indonesia ${ }^{3}$
}

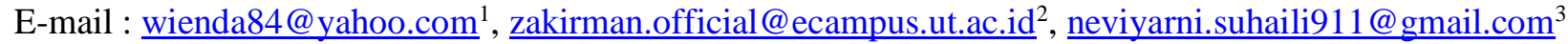

\begin{abstract}
Abstrak
Pekerjaan berkaitan dengan kehidupan seseorang dan tingkat sosial dalam masyarakat. Tingginya angka pengangguran saat ini dapat disebabkan oleh kurangnya kesiapan lulusan lembaga pendidikan khususnya lulusan perguruan tinggi dalam menghadapi dunia kerja. Untuk mengatasi masalah tersebut beberapa perguruan tinggi telah menerapkan layanan bimbingan konseling karir. Penelitian ini bertujuan untuk melihat sejauh mana manfaat yang dirasakan alumni dan potensi dampak sosial yang ditimbulkan dari pelaksanaan layanan bimbingan konseling karir di tingkat universitas. Jenis penelitian ini adalah deskriptif kualitatif, dengan responden yang diambil adalah beberapa lulusan dari dua universitas terkemuka di Sumatera Barat, yaitu IAIN Batusangkar dan UIN IB Padang. Data dalam penelitian dikumpulkan dengan menggunakan kuesioner yang disebarkan secara acak kepada 42 responden secara online. Setelah pengisian kuesioner secara online dapat dilakukan dengan menganalisis data terkait mengenai dampak sosial yang dirasakan alumni pasca dilaksanakannya kegiatan bimbingan karir oleh pihak universitas. Berdasarkan analisis data yang telah dilakukan, dapat disimpulkan bahwa kegiatan bimbingan konseling karir menurut para alumni terbukti sangat efektif dalam membantu mendapatkan pekerjaan. Secara tidak langsung dengan adanya layanan bimbingan konseling karir dapat mengurangi angka pengangguran sehingga akan berdampak signifikan secara sosial di lingkungan masyarakat.
\end{abstract}

Kata kunci: Pandangan Alumni, Tinjauan Dampak Sosial, Bimbingan Konseling Karir

\begin{abstract}
Work is related to one's life and social level in society. The current high unemployment rate can be caused by the lack of preparedness of graduates of educational institutions, especially university graduates facing the world of work. To overcome this problem several universities have implemented career counseling guidance services. This study aims to see how far the benefits felt by alumni and the potential social impact caused by the implementation of career counseling guidance services at the university level. This type of research is descriptive qualitative, with samples taken are some graduates from two leading universities in West Sumatra, namely IAIN Batusangkar and UIN IB Padang. Data in the study were collected using a questionnaire distributed randomly to 42 respondents online. After filling out the questionnaire online, it can be done by analyzing the data related to the social impact felt by the alumni after the implementation of career counseling activities by the university. Based on the data analysis that has been carried out, it can be concluded that career counseling guidance activities according to the alumni proved to be very effective in assisting in obtaining jobs. Indirectly with the existence of career counseling guidance services can reduce the unemployment rate so that it will have a significant impact socially in the community environment.
\end{abstract}

Keywords: Alumni View, Social Impact Review, Counseling Career

Copyright (c) 2021 Wienda Gusta, Zakirman, Neviyarni

$\triangle$ Corresponding author:

Email : zakirman.official@ecampus.ut.ac.id

DOI : https://doi.org/10.31004/edukatif.v3i6.1609

ISSN 2656-8063 (Media Cetak)

ISSN 2656-8071 (Media Online)

Edukatif : Jurnal Ilmu Pendidikan Vol 3 No 6 Tahun 2021 p-ISSN 2656-8063 e-ISSN 2656-8071 
5110 Alumni Views and the Potential of Social Impact on Career Counselling Guidance Policy at the University Level - Wienda Gusta, Zakirman, Neviyarni

DOI: https://doi.org/10.31004/edukatif.v3i6.1609

\section{INTRODUCTION}

Learning is a process to improve a person's skills. Learning context is not only related to the learning process in the classroom but further than that learning can be done in an unlimited place and space. The concept of learning is often interpreted as an activity that must be taken to complete an education. Learning means receiving new information and knowledge gained during the education process (Minogue, Murphy, and Salmons 2018).

Expertise gained by someone is a product and the result of the implementation of learning activities. Insights and expertise gained are very useful for someone to compete in the world of work. Therefore, improving the quality of graduates will certainly affect the level of expertise that is owned by prospective job seekers later. Every person who has good skills and abilities will certainly be able to easily get a job.

The desired work can easily be achieved not only by relying on expertise. Furthermore, debriefing given to prospective job seekers/ graduates will contribute to the success of getting a job. Based on the survey that was conducted, $93.75 \%$ of respondents whose campuses had provided career guidance said that they were very helpful in getting a job. Career guidance provided can provide brief knowledge about the world of work, things that must be prepared, and how to deal with competition in the world of work today.

Work is closely related to one's life and social level. The simple amount of unemployment will influence the social life in society. Indirectly, many parties who are in the category of not being lucky because they do not have a job will also have a social impact. The impact that arises is the negative opinion that develops in the community about the character of people who have not worked to the impact of the unrest in social life that has the potential to cause noise in the community.

High unemployment can be caused by several factors including the limited expertise possessed and the unpreparedness of a person towards the world of work. It is undeniable, in terms of science, every good graduate candidate in a tertiary institution has been equipped with sufficient skills and knowledge in the field being studied. On the other hand, the role of campus also contributes to the success of someone getting a job. Based on the previous study, (Zulfa 2020) stated that guidance and counseling services in universities students need. The Career Guidance Service Unit (UPBK) in the university will make it easier for students to obtain information related to student careers. Cooperation between UPBK and service units as well as alumni organizations will also enlarge and expand useful job information for students. Moreover, (Lestari 2017), also mentions that application of -based career guidance life skills (life skills) is at least influenced by three factors: 1) characteristics of career guidance. 2) strategy and 3) implementation, characteristics of career guidance used.

Furthermore, the results of previous research conducted by Siti Fadhilah et al show that: that career guidance through the provision of life skills and link and match is very important as an effect on increasing students in carrying out work. It means that career guidance in higher education is through the provision of life skills is effective in providing student assistance when the waiting period to get a job is short. For students who haven't got a job, some of them haven't finished studying or graduated in semester 9 (nine). (Fadhilah, Siti S. Asrowi. HA, Chadijah. Muslim 2015).

Likewise, research by Hermi Prasmawati assumes that career guidance is very important for students in providing provisions for preparing to enter the world of work following what is needed in the world work so that their competencies can develop properly. Other than that, With this career guidance, final semester students, fresh graduates, graduates, or alumni who are in the waiting period to get jobs will be better prepared to face the demands for work so that they can minimize problems that will arise related to unprepared worries enter the world of work (Pasmawati 2018). Zulfa stated that based on the analysis that has been carried out, counseling guidance programs are eligible applied by any colleges to create alumni career success in the 
5111 Alumni Views and the Potential of Social Impact on Career Counselling Guidance Policy at the University Level - Wienda Gusta, Zakirman, Neviyarni

DOI: https://doi.org/10.31004/edukatif.v3i6.1609

future (Zulfa 2018). Therefore, the leadership and all the ranks of universities can synergy for the creation of a service policy career counseling guidance at universities.

A campus can routinely and periodically take action by making policies on the implementation of career counseling guidance. The existence of career counseling guidance activities is based on surveys that can help prospective graduates to be ready to face the world of work (Crişan, Pavelea, and Ghimbuluţ 2015). Based on the problems that have been raised, researchers are interested in reviewing the "Views of Alumni and the Potential of Social Impacts on Career Counseling Guidance Policies at the University Level".

Social Life in Society

Social life in society does not always have a good and beneficial impact on all parties. The impacts that arise as we often observe are criminal cases or social problems that are troubling the public. Social problems can be defined as symptoms or phenomena that arise in life in society (Castanheira 2015). Social problems are an inseparable part of social life in society. This is because social problems arise as a form of human culture and human interaction. Social symptoms can be said to be social problems if several things happen, namely: The existence of friction between social values and social actions, the source of social problems is the result of a social phenomenon in society, the existence of real and hidden social problems.

The problem faced by a person may not necessarily be called a social problem. A social problem can arise if: There are interactions or relationships between individuals in society that hinder the achievement of important goals of most members of society, social organizations in society cannot regulate the relationships between individuals in the face of external threats. Social symptoms are an event that occurs in a society that involves social and moral values. Undeniably, social symptoms can create friction in the community and can trigger social change. Social symptoms can be a marker that there are values and norms of society that have been running as they should. Awareness of education is one of the effects of the emergence of social symptoms. Social symptoms that have been overcome will bring the understanding that "education is important" (Panhwar et al. 2017). As a result, people will be more aware of education and try to get access to education, especially formal education, which is even better.

The thing that can be a potential emergence of social symptoms is about the field of work. In today's society, the work that someone has will determine his social position and level in society. Work is sensitive in society. A person who does not have a permanent job will indirectly affect his social life and his social environment in society (Boreham, Povey, and Tomaszewski 2016). The high rate of unemployment is one of the forms that work is hard to come by today. The unavailability of broad employment opportunities will create turmoil in the community. One of the causes of the many unemployed at this time is the unpreparedness of prospective job seekers to follow the competition in the world of work. The most quickly taken effort is to provide supplies to prospective graduates of a university who will seek employment (Brand, 2015). The intended provision is training and understanding of the world of work to be pursued. This activity can be packaged in the form of organizing career counseling guidance services.

\section{Career Counseling Guidance}

A recent study, Americans will spend a third of their lives at work (Weirik 2018). Stress at work can cause depression, so getting a desired and satisfying job is considered important for one's health. Furthermore, this condition evaluates the existence of career counseling guidance services that can help and facilitate job seekers later (Ceu Taveira and Nazare Loureiro 2014). A career counselor can become a therapist and is trained to provide career information resources, discuss career development, and manage and interpret talent. Students can refer to a counseling counselor in high school before applying to college and then in college before choosing or changing majors (Dik, Sargent, and Steger 2008). Career counseling services not only can help a person to choose a department in a college but can further direct someone to the desired and desired job. 
5112 Alumni Views and the Potential of Social Impact on Career Counselling Guidance Policy at the University Level - Wienda Gusta, Zakirman, Neviyarni

DOI: https://doi.org/10.31004/edukatif.v3i6.1609

Choosing a job is an important task, but it may also be heavy and difficult. It may not be easy to decide what type of work is most suitable. For this reason, career counseling services are available to help people assess their skills, needs, and desires to find a career that suits them (Mihaela 2015). Some short sentences that are considered by someone in choosing a job include things to do, activities that are most liked, skills mastered, skills possessed, experience and education that has been achieved, to what extent he needs the income for life in the future.

In the study of career counseling, the counselor will help one explore skills and strengths, consider the level of education and provide advice on continuing education, and determine interests and personality types (Jain 2017). Counselors can also do aptitude tests. Some of the things that are interesting to be a career counseling guidance study are Skills or talents Work environment, Opportunities for change or progress in career, education needed for the desired career.

\section{RESEARCH METHODOLOGY}

Based on the problems raised, this type of research is descriptive qualitative. This study aims to see the social impact caused by the enactment of a career counseling guidance policy at the university level. Data collected in this study were analyzed using an online-based survey application. Questionnaires that have been designed are distributed to college alumni who have held career counseling guidance activities. The selected alumni groups are graduates of Imam Bonjol Padang UIN and Batusangkar IAIN. Questionnaires were distributed randomly and filled by 42 respondents with different graduated years, ranging from 1983 to 2018 . This study also analyzed respondents' answers related to the content and content of the study of career counseling guidance that is most needed to prepare prospective graduates to compete in the world of work today.

\section{RESULT AND DISCUSSION}

Career counseling guidance is one of the efforts that can be taken by educational institutions, especially a college, to prepare prospective graduates to be ready to face the world of work. The program and the implementation of career counseling guidance services can be carried out systematically every year. Based on the initial analysis conducted, career counseling guidance activities have begun to be carried out at two universities namely IAIN Batusangkar and UIN IB Padang since 1983. However, these activities are still incidental and not programmed every year.

Career counseling guidance programs that have been endeavored by the university include holding seminars that are related to the working world picture of graduates and some alumni say they have been provided with career counseling guidance courses. The seminar program held is one of the alternative steps that can be taken to organize preparations for prospective graduates to have provisions before working. The seminars that were held could overcome the limitations of the implementation which had quite a large number of participants. The introduction to the world of work that has been held by the university is presented in table 1.

Table 1

Summary of the Forms of Career Counseling Guidance Programs Organized by the University

\begin{tabular}{lll}
\hline No & Program form & Information \\
\hline 1 & Seminar & $\begin{array}{l}\text { Can be effectively used for } \\
\text { participants with a large enough } \\
\text { amount }\end{array}$ \\
\hline 2 & $\begin{array}{l}\text { Stimulus about the world of } \\
\text { entrepreneurship }\end{array}$ & $\begin{array}{l}\text { Conduct some activities and } \\
\text { understanding about the world of } \\
\text { entrepreneurship }\end{array}$ \\
\hline 3 & Introduction to information & The introduction of the world of work \\
\hline
\end{tabular}


5113 Alumni Views and the Potential of Social Impact on Career Counselling Guidance Policy at the University Level - Wienda Gusta, Zakirman, Neviyarni

DOI: https://doi.org/10.31004/edukatif.v3i6.1609

\begin{tabular}{lll}
\hline & technology assistance & $\begin{array}{l}\text { can be done by providing information } \\
\text { technology-assisted knowledge and } \\
\text { experience }\end{array}$ \\
\hline 4 & Integrated in the course & $\begin{array}{l}\text { For some departments, career } \\
\text { counseling guidance is integrated in } \\
\text { the course }\end{array}$ \\
\hline 5 & Practice field & $\begin{array}{l}\text { Looking at field conditions when PL } \\
\text { activities can provide real conditions } \\
\text { of work at this time }\end{array}$ \\
\hline 6 & Field data retrieval & $\begin{array}{l}\text { Some students are instructed to take } \\
\text { the data needed to complete the } \\
\text { course in the field. Indirectly this will } \\
\text { provide students with experience } \\
\text { about the world of work today }\end{array}$ \\
\hline 7 & Coaching Clinic & Done before the PL \\
\hline 8 & Job Fair & Organized by the University \\
\hline 9 & Micro Teaching & Compulsory education subjects \\
\hline
\end{tabular}

Some of the programs offered above have proven to have considerable benefits in the job search process for graduates. According to alumni who have worked in several agencies, career counseling guidance can be a provision for work and make it easier for prospective job seekers to act and make decisions about the world of work. Career counseling guidance can also help job seekers to get decent jobs. This is because the counseling guidance services provided will direct prospective seekers to work to get tricks, strategies, and techniques to get a job in accordance with their competencies. The introduction of the world of entrepreneurship also did not escape being studied in the career counseling guidance services provided. Basically, not always job seekers become workers in agencies or several companies. But job seekers are also directed to create jobs and absorb labor. For this reason, studies on the concept of entrepreneurship are deemed necessary to become compulsory material in every career counseling guidance service. The effectiveness of career counseling guidance services can be indicated by the results of the survey where it can be concluded that $95 \%$ of respondents agree with the statement that career counseling guidance can help in getting a job.

In order for the implementation of counseling guidance services to be better and better, some input from alumni can be considered. One of them is the factors that influence prospective graduates to get the desired job. The factors are described in table 2.

Table 2

Factors that Influence Someone to Get a Job in Alumni View

\begin{tabular}{lll}
\hline No & Factor affecting & Information \\
\hline 1 & Insight & Internal factors \\
\hline 2 & Building networks & External Factors \\
\hline 3 & Self-potential & Internal factors \\
\hline 4 & Information disclosure & External Factors \\
\hline 5 & Activity in the organization & External Factors \\
\hline 6 & Persistence & Internal factors \\
\hline 7 & Value & Internal factors \\
\hline 8 & Luck & External Factors \\
\hline 9 & Experience & Internal factors \\
\hline 10 & Communication & Internal factors \\
\hline
\end{tabular}

The ten factors summarized from the views of these alumni can be used as a reference by the relevant parties who are authorized to carry out career counseling guidance services. The top factor most alumni mentioned and expressed was insight. Basically, insight is a picture of the quality of prospective job seekers. Insights can be related to the knowledge and skills possessed by someone. 


\section{Alumni Views and the Potential of Social Impact on Career Counselling Guidance Policy at the University Level - Wienda Gusta, Zakirman, Neviyarni \\ DOI: https://doi.org/10.31004/edukatif.v3i6.1609}

The alumnus's view can also be taken into consideration in preparing career counseling guidance materials at the university level. One that seeks attention is the concept of teamwork. This is felt necessary to be developed in prospective job seekers because in principle when someone works in an agency will face many people with various backgrounds of personality. A person's expertise in building cooperation with colleagues can be a considerable consideration in order to be accepted into a job. Another material that also needs to be given in career counseling guidance services is about fighting power. Most prospective job seekers fail not because of the lack of adequate skills but are influenced by a low fighting factor in themselves. Therefore, the provider of career counseling guidance services can strive to strengthen the understanding of prospective graduates later with the concept of fighting power.

Based on the views and studies that have been carried out in the face of career counseling guidance policies implemented at two universities, several analyzes can be carried out on the social impacts felt by alumni. The most important social impact is related to the work that has been undertaken by the alumni. Indirectly, the implementation of career counseling guidance services contributes to and influences the success of alumni in obtaining employment. Career counseling guidance services provide insight into the world of work, insights, and skills that must be prepared as well as tricks and strategies in getting a job.

A person's work status will influence his position in the community. The view of society today is strongly influenced by one's life economically. The level of one's social strata is viewed based on the work and material that has been owned. This condition allows the occurrence of social changes in a person with an increase in career and employment.

Career counseling guidance services can help a person achieve the desired job. Of course, this will affect and impact one's social life later. Career counseling guidance also contributes to determining a person's life in the future. In summary, it can be concluded that counseling guidance services also contribute to improving one's life socially, so that the implementation of this service is expected to be carried out by every university that will release graduates to face the world of work.

\section{CONCLUSION}

Career counseling guidance services are one of the efforts taken by the university to assist prospective graduates in getting the desired job. The main benefit felt by graduates whose colleges have held career counseling guidance activities is to get tricks and strategies in getting a job. The career counseling guidance program that is carried out is at least able to provide insight into the factors that influence a person to be accepted at work and what internal factors need to be prepared to face the world of work. Undeniably, work can be used as a reference by the public about how a person's social life. Often the social problems that occur in the community are influenced by a person's work factor. Therefore, indirectly career guidance counseling services have helped someone in getting his job so that it will have an impact on social life changes in the community's view.

\section{REFERENCES}

Boreham, Paul, Jenny Povey, and Wojtek Tomaszewski. 2016. "Work and Social Well-Being: The Impact of Employment Conditions on Quality of Life." International Journal of Human Resource Management 27(6): 593-611.

Castanheira, Filipa. 2015. "Predicting Marital Happiness and Stability from Newlywed Interactions Published by : National Council on Family Relations Predicting Marital Happiness and Stability from Newlywed Interactions." Journal of Marriage and Family 60(1): 5-22.

Ceu Taveira, Marea do, and Marí Nazare Loureiro. 2014. "Calidad En Educación Superior y Orientación: Eficacia de Un Seminario de Gestión Personal de La Carrera Para Pre Graduados.” Revista Electrónica Interuniversitaria de Formación del Profesorado 17(3). 
5115 Alumni Views and the Potential of Social Impact on Career Counselling Guidance Policy at the University Level - Wienda Gusta, Zakirman, Neviyarni

DOI: https://doi.org/10.31004/edukatif.v3i6.1609

Crişan, Claudia, Anişoara Pavelea, and Oana Ghimbuluţ. 2015. "A Need Assessment on Students' Career Guidance." Procedia - Social and Behavioral Sciences 180(November 2014): 1022-29.

Dik, Bryan J., Adam M. Sargent, and Michael F. Steger. 2008. "Career Development Strivings: Assessing Goals and Motivation in Career Decision-Making and Planning." Journal of Career Development 35(1): 23-41.

Fadhilah, Siti S. Asrowi. HA, Chadijah. Muslim, Mudaris. 2015. "Pemberian Life Skills Dan Link and Match Untuk Pekerjaan Pendek.” Junal Paedegogia 18(2): 10-20.

Jain, Paras. 2017. "Impact of Career Guidance and Counseling on Student'S Career Development." International Journal of Research -GRANTHAALAYAH 5(6): 49-52.

Lestari, Indah. 2017. "Meningkatkan Kematangan Karir Remaja Melalui Bimbingan Karir Berbasis Life Skills.” Jurnal Konseling GUSJIGANG 3(1): 17-27.

Mihaela, Andreea. 2015. "A Research on the Educational Counseling and Career Guidance in Romania." European Scientific Journal 2(February): 1857-7881.

Minogue, Laura, Carole Murphy, and Kim Salmons. 2018. "Embedding Learning Development; a Model for Collaborative Practice." Journal of Learning Development in Higher Education (13).

Panhwar, Uzma et al. 2017. "4.Critical Analysis of the Impact of Job on the Social Status of Women in Pakistan." Journal of Education and Practice 8(6): 17-24.

Pasmawati, Hermi. 2018. "Urgensi Bimbingan Karier Di Perguruan Tinggi Untuk Membantu Kesiapan Mahasiwa Tahun Akhir Memasuki Dunia Kerja.” Jurnal Ilmiah Syi’ar 18(1): 1.

Weirik, Mark. 2018. Vocational Career Guidance in Dutch Higher Vocational.

Zulfa. 2018. "Profil Penasehat Akademis (Pa) Dalam Pelayanan Konseling Karier Di Perguruan Tinggi." Jurnal Counseling Care 2(1): 28-41.

Zulfa, Mona Yulia. 2020. “Mau’izhah Vol. X No.1 Januari - Juni 2020 219.” X(1): 219-40. 